\title{
COMPOSITION AND PHYSICOCHEMICAL PROPERTIES OF STARCH FROM CHRIST THORN SEEDS
}

\author{
${ }^{*}$ Izuagie, T., ${ }^{1}$ Hassan, L. G., ${ }^{2}$ Uba, A., ${ }^{3}$ Achor, M. $^{3}$ and Sahabi, D. M. ${ }^{4}$ \\ ${ }^{1}$ Department of Natural Sciences, Sokoto State Polytechnic, Sokoto. \\ ${ }^{2}$ Department of Pure and Applied Chemistry, Usmanu Danfodiyo University, Sokoto. \\ ${ }^{3}$ Faculty of Pharmaceutical Sciences, Usmanu Danfodiyo University, Sokoto. \\ ${ }^{4}$ Department of Biochemistry, Usmanu Danfodiyo University, Sokoto. \\ *Correspondence author: oshiobugie2007@yahoo.com, 08068992243
}

\begin{abstract}
Starch was extracted from seeds of Christ Thorn by hot water extraction method. The composition and physicochemical properties of the extracted starch were determined using standard methods. The results obtained from the analyses revealed that the \% yield of starch was $43.2 \%$, while moisture content, ash content, starch protein and starch lipid were $7.8 \%, 0.01 \%, 0.12 \%$ and $0.32 \%$ respectively. The results also showed amylose content of $24.6 \%$; swelling power of $37.5 \mathrm{~g} / \mathrm{g}$, solubility of $2.1 \%$, amylose leaching of $3.7 \%$ and gelatinization temperature of $68^{\circ} \mathrm{C}$. From the results, the paper concludes that with minor modifications, the seeds can be used as alternative sources of starch for industrial products.

Keywords: Christ thorn, starch, amylose, seeds
\end{abstract}

INTRODUCTION

Starch is a common constituent of higher plants and the major form in which carbohydrates are stored in plants' organ (Vasanthan, 2001; Shannon et al., 2009). Organs and tissues containing starch granules include pollen, leaves, stems, woody tissues, roots, tubers, bulbs, rhizomes, fruits, flowers, pericarps, cotyledons, embryo and endosperm of seeds (Shannon et al., 2009).

Native starch is a relatively inexpensive and versatile product and the raw material for production of many modifications, sweeteners and ethanol (Madigan, 2003; Brown and Poon, 2005; Schwartz and Whistler, 2009). Since the early 1930s, carbohydrate chemists have developed numerous products that have greatly expanded starch use and utility (Shannon et al., 2009). Its applications include: fillers, binders, disintegrants, lubricants in tablet formulations super-absorbent products (Madigan, 2003) and flocculants in the purification of water (Marton, 2003). Starch is also used in textiles, cosmetics, agrochemicals, constructions and bioplastics (Madigan, 2003; Rocher, 2003; Anil Group Limited, 2011).

At present, the world's major sources of starch include wheat, rice, maize, yam, cassava and potato (vander et al., 2002). Alternatives like seeds are currently being explored for commercial quantity of starch for the production of industrial and pharmaceutical products (Madigan, 2003; Science Tech entrepreneur, 2010). One common seed that could be explored for starch is the seed of Christ thorn also known as Ziziphus spina-christi.

Christ thorn or Kurna in Hausa is a shrub or a tree belonging to the genius Ziziphus in the buckthorn family (Rhamnaceae) (Anthony, 2005). It is widely distributed in the tropical and subtropical regions of the world and is reported to be native to a vast area of Africa stretching from Mauritania through the
Sahara and Sahelian zones of West Africa to the Red Sea (Orwa et al., 2009). It is drought hardy, very resistant to heat and can be found in desert areas with even $100 \mathrm{~mm}$ rainfall annually. The tree is frost tender, can withstand water logging for up to 2 months and 8-10 months of dry season. The plant has a height of $20 \mathrm{~m}$ and a diameter of $60 \mathrm{~cm}$. It has a light-grey bark, which is very cracked, scaly and has a twisted trunk. It is also very branched, with crown thick; whitish and flexible shoots. The plant is also characterized with thorns in pairs, one straight and the other curved (Orwa et al., 2009). Its leaves are glabrous on the upper surface, finely pubescent below, with margins almost entire ovatelanceolate or ellipsoid and comspicuous lateral veins. It has an average size of $50 \mathrm{~g}$ with a fruit of about $1 \mathrm{~cm}$ in diameter containing a single large seed (Orwa et al., 2009).

Various parts of the plant are used for different purposes. For example, its wood is used as timber for spear shafts, posts, roofing beams, utensils and cabinet making while the leaves are used for animal feeds. The leaves have even been reported to contain various alcaloids, including ziziphine, jubanine and amphibine, alpha terpinol, linalol and diverse saponins and as such can be used for medicine (Ismail, 1998). Its fruit is edible and could serve as food as it is generally regarded as save (GRAS). It is against this background that this research is aimed at isolating and analysing the composition and physicochemical properties of starch from Christ thorn seeds in order to ascertain if it can be used as an alternative source of cheap starch for industrial applications.

\section{MATERIALS AND METHODS}

Seeds of Christ thorn were collected from waste sites around Sokoto metropolis and identified at the Botany Unit, Usmanu Danfodiyo University, Sokoto. 
The seeds were washed thoroughly with distilled water, decorticated to remove skin, dried and ground into flour, which was stored in an air-tight container before extraction of the starch. All reagents used were of analytical grade.

\section{Total starch content}

Total starch content of the seeds was determined by first extracting soluble sugars with ethanol (95\%) and the residual starch was hydrolysed with perchloric acid into monosaccharides. The sugar was colorimetrically determined with phenol-sulphuric acid by means of a UV-VIS spectrometer (Duboise et al., 1956; Kalenga et al., 1981; Ezeagu et al., 2011). The total starch content obtained was used to determine the yield.

\section{Extraction of Starch}

The starch was extracted using hot water extraction method (Chavan et al., 2010; Kevate et al., 2010). The flours were soaked in $1000 \mathrm{~cm}^{3}$ beakers in a thermostatic water bath at a constant temperature of $40^{\circ} \mathrm{C}$ for about $24 \mathrm{hrs}$. One part of soaked flour and three parts of distilled water were blended for $3 \mathrm{~min}$ at medium and high speed. The resultant slurry was passed through double layer of muslin cloth and then centrifuged at $5000 \mathrm{rpm}$ for $20 \mathrm{~min}$. The supernatant was discarded and the sediment resuspended in excess $0.02 \% \mathrm{NaOH}$ to remove any residual proteins and phenolic compounds. After standing for 4 hours, the supernatant was discarded. This procedure was repeated 6-8 times until the supernatant became colourless. The final sediment was suspended in distilled water and then subjected to filtration through $0.045 \mathrm{~mm}$ sieve, neutralized to $\mathrm{pH} 7.0$, filtered on Buchner funnel and thoroughly washed with distilled water. The filtered cake was dried overnight at room temperature, ground to powder and stored in an airtight glass bottle before further analysis (Chavan et al., 2010; Kevate et al., 2010).

\section{Moisture Content Determination}

This was determined by drying the starch samples at $110^{\circ} \mathrm{C}$ for at least 24 hours until the weight became constant (Ezeagu et al., 2011; Lee et al., 2007).

\section{Total Ash Determination}

Ash content was estimated by the method of Chavan et al. (2010).

\section{Starch Protein Determination}

This was done using the method of AOAC (1990).

\section{Starch Lipid Determination}

This was assayed by extraction with petroleum ether in a soxhlet extractor as described in Ezeagu et al. (2011).

\section{Amylose Content Determination} (2007).

This was carried out as described by Barry

\section{Granular Morphology and Size}

Granular morphology and size were determined using an optical microscope equipped with ocular and calibrated stage micrometers. The starch sample was suspended in glycerol to ensure uniformity of the test sample. One drop of the suspension was placed on a slide glass and used as the test specimen directly on the microscope (General Test, 2011).

\section{Gelatinization Temperature Determination}

The gelatinization temperature of the starch samples was determined by making $0.29 \% \mathrm{w} / \mathrm{v}$ suspension of each sample in water in a $25 \mathrm{~cm}^{3}$ beaker and heating in a thermostated water bath at $40^{\circ} \mathrm{C}$. The temperature was gradually raised by about $2^{\circ} \mathrm{C}$ and samples were withdrawn and observed under a polarized microscope after each rise to ascertain the temperature at which the granules lost their polarization crosses totally (Linus, 1995).

\section{Swelling Power and Solubility}

The method of Nadiha et al. (2010) was used in determining swelling power and solubility.

\section{Extent of Amylose Leaching (AML)}

This was determined using the method of Chrastil (1987) as described in Hoover and Senanayake (1996).

\section{Freeze Thaw Stability}

This was determined as described in Hoover and Senanayake (1996) and Odeku and Itiola (2007). Starch gels (6\% w/v, dry basis) were subjected to cold storage at $4^{\circ} \mathrm{C}$ for $16 \mathrm{~h}$ (to increase nucleation) and then frozen at $-16^{\circ} \mathrm{C}$. To measure freeze-thaw stability, the gels frozen at $-16^{\circ} \mathrm{C}$ for $24 \mathrm{~h}$ were thawed at $25^{\circ} \mathrm{C}$ for $6 \mathrm{~h}$ and then refrozen at $-16^{\circ} \mathrm{C}$. Five cycles of freeze-thaw were performed. The excluded water was determined by centrifuging the tubes (30 mm diameter $\times 100 \mathrm{~mm}$ ) at $1000 \mathrm{~g}$ for 20 min after thawing.

\section{RESULTS AND DISCUSSION}

\section{Yield and Compositions}

The results for starch yield and composition is presented in Table 1. It shows that starch yield was $43.2 \%$ with a purity of $91.75 \%$. The yield is greater than values obtained by Verwimp et al. (2004) for rye starch (42.2\%) and Chavan et al. (2010) for horse gram starch (22 to $31 \%$ ) but less than values obtained by Nadiha et al. (2010) for sago, potato and corn starches, which were $93.6 \%, 93.4 \%$ and $96.5 \%$ respectively.

The high yield most probably is due to the granular size which allows for easy extraction of the starch granule. The results also showed very low moisture, ash, lipid and protein contents (Table 1), which are within the range of values obtained for rye starch ( 0.24 to 0.48 for lipids and 0.09 to 0.47 for proteins) (Verwimp et al., 2004; Lee et al., 2007). This is an indication of the absence of endosperm proteins and absence of most of the non-starch lipids in the sample analyzed as the nitrogen content of isolated starches represents the endosperm storage proteins, lysophospholipids and proteins located inside starch granules (Chavan et al., 2010). Thus, the results of the analysis have shown that the extracted starch has low protein and lysophospholipid contents, which could adversely affect the physicochemical properties of the starches and make starch extraction difficult (Tester and Morrison, 1990 and Chavan et al., 2010). 


\section{Amylose Content}

The amylose content was $24.6 \%$ which is higher than those reported by Hoover and Senanayake (1996) for oats starches (22.2 to $22.5 \%$ ) and those reported by Sandhu and Singh (2007) for corn starches (16.9 to $21.3 \%$ ) but was less than those reported by Chavan et al.(2010) for Horse Gram (34.00 to 36.30\%). It was also found to be within the range reported by Hoover et al. (2010) for pulse starches (11.6 to $88.0 \%)$.The amylose content of starch determines crystallinity and thus affects solubility (Yuan et al., 2007), and this is very important in determining the applicability of the starch.

\section{Granular Morphology and Size}

Optical micrographs [Plates 1 (a) and (b)] show that the shape of the starch granule was oval. Starches of oval shape have been reported by Hoover et al. (2010). The starch had small granular size which was less than 50 . Granular size affects the packing properties of the starch (Odeku and Itiola, 2007).

\section{Gelatinization Temperature}

The results in Table 2 show that the starch has an onset temperature of $68.8^{\circ} \mathrm{C}$ and a conclusion temperature of $72.3^{\circ} \mathrm{C}$. Thus, showing a gelatinization range of $3.5^{\circ} \mathrm{C}$, which is in agreement with values reported for pulse starches by Hoover et al. (2010). The gelatinization property of starch is a determining factor in its functionality in food applications (Evans and Haismann, 1982).

\section{Swelling Power, Solubility and Extent of Amylose Leaching}

The major factor that controls swelling behaviour and solubility of starch is the strength and character of the miscellar network within the granule, which in turn is dependent on the degree and kind of interaction (Teli et al., 2009). Figure 2 shows values obtained for swelling power, solubility and extent of amylose leaching over a range of 0 to $90^{\circ} \mathrm{C}$. The three parameters increased with rise in temperature. This was most marked for swelling power between 85 and $90^{\circ} \mathrm{C}$. The swelling power and extent of amylose leaching were comparable to values reported for pulse and oat starches (Hoover and Senanayake, 1996; Hoover et al., 2010). Equally, researchers have shown that swelling is a property of amylopectin and that, in normal cereal starches, amylose and lipid actively inhibit swelling under conditions where amylose lipid complexes are likely to form (Tester and Morrison, 1990). Thus, the low lipid content of the starch enhances the swelling power between 85 and $90^{\circ} \mathrm{C}$, which is very useful in food application of the starch. The extent of amylose leaching which is higher than reported for pulse starches may be due to the higher amylose content in the starch (Hoover et al., 2010).

\section{Freeze-Thaw Stability}

On cooling starch granules after gelatinization, the starch chains (amylose and amylopectin) in the gelatinized paste interact, leading to the formation of a more ordered structure. These molecular interactions are collectively termed retrogradation (Miles et al., 1985; Hoover and Senanayake, 1996). Retrogradation is accompanied by increases in the degree of crystallinity and gel firmness and exudation of water (syneresis) (Hoover and Senanayake, 1996). Figure 3 gives the \% syneresis for the starch after a series of five cycles of freeze-thawing and these compared very well with values obtained for oat starches (Hoover and Senanayake, 1996).

Table 1: Composition of Christ thorn starch

\begin{tabular}{ll}
\hline Parameter & Composition \\
\hline Total starch content (\%) & $48.6 \pm 1.2$ \\
Yield (\%) & $43.2 \pm 0.9$ \\
Starch purity $(\%)$ & $91.75 \pm 2.6$ \\
Moisture content $(\%)$ & $7.8 \pm 0.4$ \\
Ash content $(\%)$ & $0.01 \pm 0.003$ \\
Starch protein $(\%)$ & $0.12 \pm 0.02$ \\
Total lipid $(\%)$ & $0.32 \pm 0.01$ \\
Amylose content $(\%)$ & $24.6 \pm 1.7$ \\
Granule shape & Oval \\
Granular size $(\mu \mathrm{m})$ & $13 \pm 1.1$ \\
Physical appearance & Off-White \\
\hline
\end{tabular}

Data were reported in means $\pm S D(n=3)$

Table 2: Gelatinization parameter of Christ Thorn starch

\begin{tabular}{ll}
\hline Parameter & Christ thorn Starch \\
\hline $\mathrm{T}_{0}\left({ }^{\circ} \mathrm{C}\right)$ & $68.8 \pm 1.3$ \\
$\mathrm{~T}_{\mathrm{mp}}\left({ }^{\circ} \mathrm{C}\right)$ & $70.6 \pm 1.2$ \\
$\mathrm{~T}_{\mathrm{c}}\left({ }^{\circ} \mathrm{C}\right)$ & $72.3 \pm 1.1$ \\
$\mathrm{~T}_{\mathrm{c}}-\mathrm{T}_{\mathrm{o}}\left({ }^{\circ} \mathrm{C}\right)$ & $3.5 \pm 0.3$ \\
\hline
\end{tabular}

Data were reported in means $\pm S D(n=3)$

Where $T_{0}=$ onset Temperature, $T_{m p}=$ midpoint Temperature and $T_{c}=$ conclusion temperature 


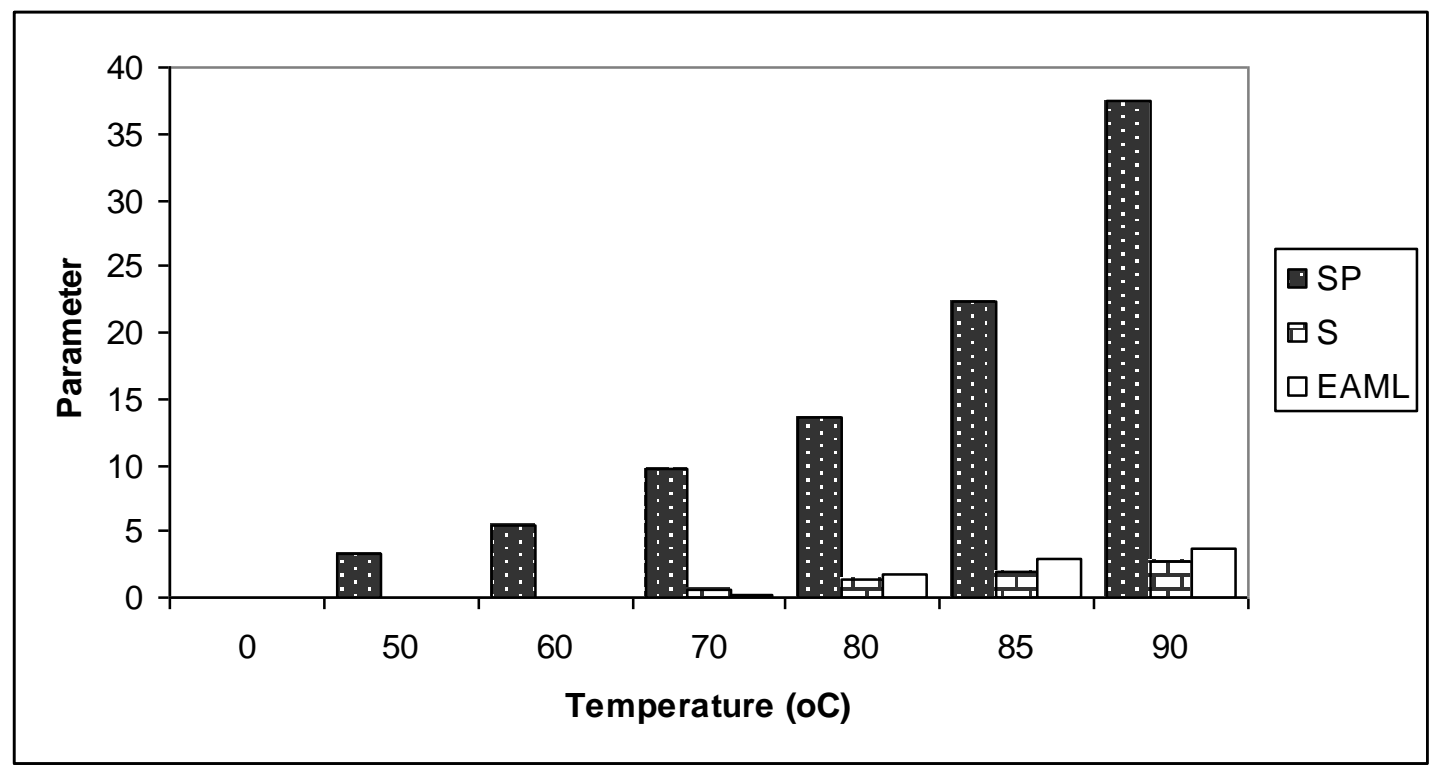

Figure 2: SP, S and EAML of Christ Thorn Starch over the range of 50 to $90^{\circ} \mathrm{C}$

Key: SP = Swelling Power, $\mathrm{S}=$ Solubility and EAML = Extent of Amylose Leaching

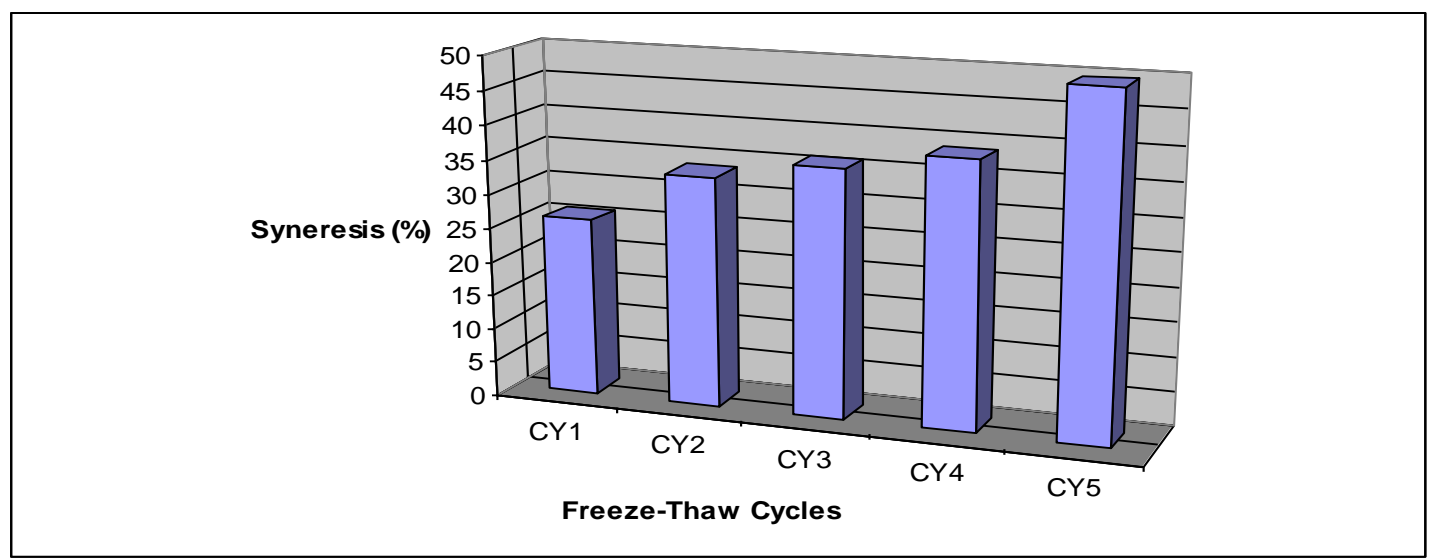

Figure 3: Freeze-Thaw Stability of Christ Thorn Starch

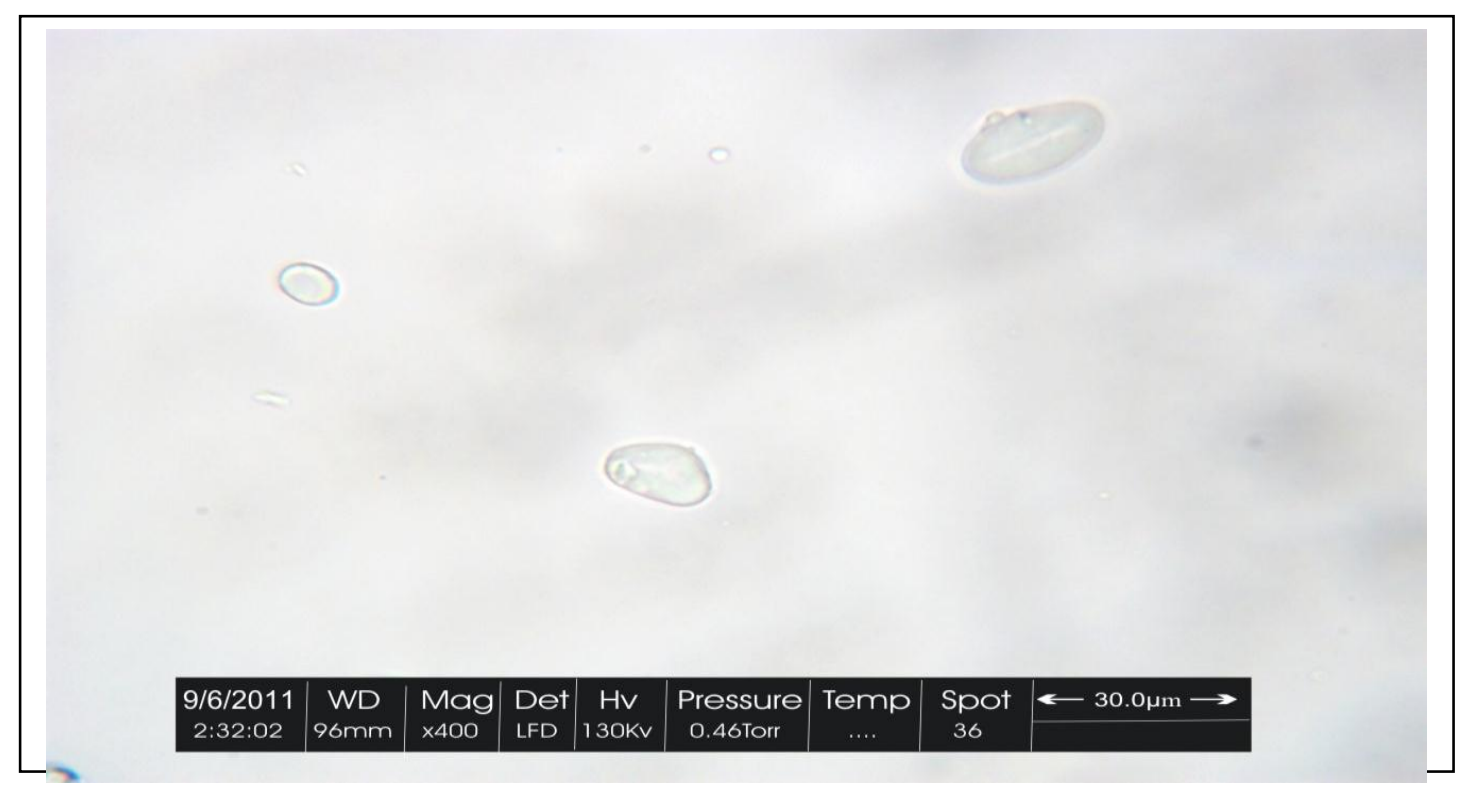

Plate 1 (a): Optical micrograph of starch extracted from Christ Thorn Seeds at x 400 magnification showing the granular shape. 


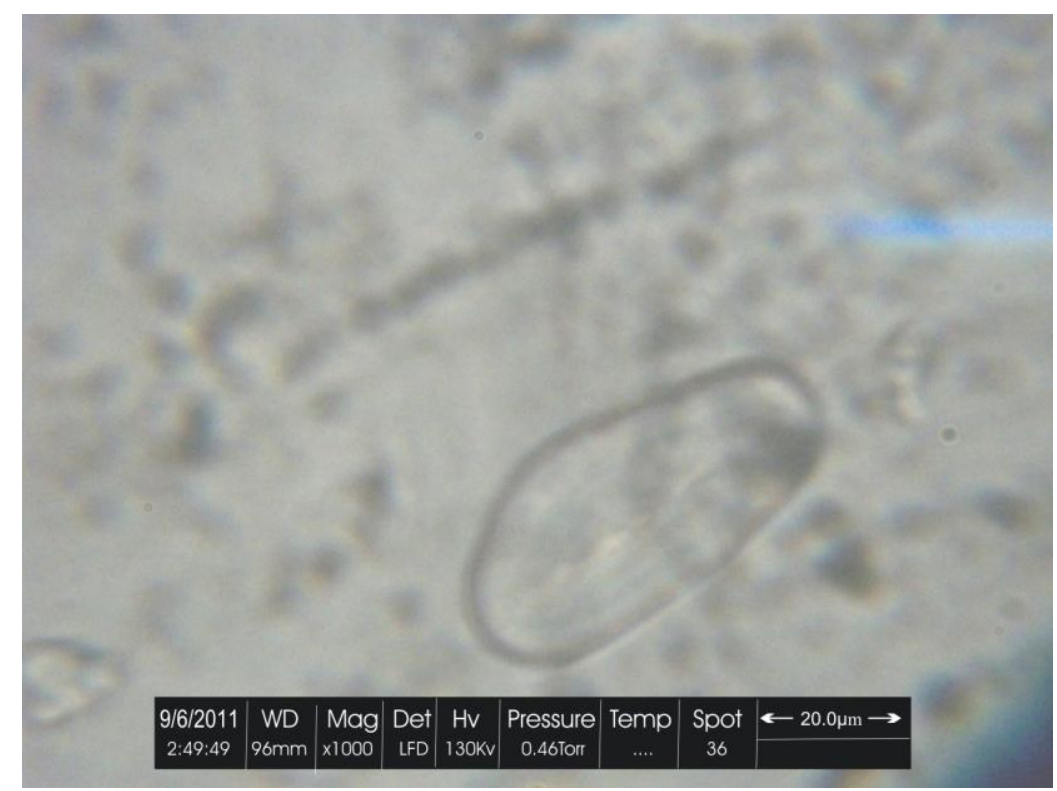

Plate 1 (b): Optical micrograph of starch extracted from Christ Thorn Seeds at x1000 magnification showing the granular shape.

\section{CONCLUSION}

The analyses performed have shown that the Christ thorn starch has a good yield and gives a composition, physicochemical properties, that compare very well with values obtained for other native starches with

\section{REFERENCES}

Anil Group Limited (2011). Redefining Starch Manufacturing in India. Foods and Pharmaceuticals. Retrieved 3/2/2011 from: http://pubs.acs.org/toc/ancham/82

Anthony, C. D. (2005); A Review of Zizyphus spinaChristi. PERSONAL CARE. Pp. $1-3$.

AOAC (1990). Association of Official Analytical Chemists. Official Methods of Analysis. 12th ed. Washington, DC.

Barry, G. (2007). Isolation of Amylose and Amylopectin from Starch. (cited from: Methods in Carbohydrate Chemistry, Vol. IV, Pp. 25 - 27).

Brown, W. H. and Poon, T. (2005). Introduction to Organic Chemistry (3rd ed.). Wiley, London. Pp. $324-341$.

Chavan, U.D.,Shinde, B. G., Kadam, S. S. and Amarowicz, A. (2010). Isolation and Characterization of Starch from Horse Gram. African Journal of Food Science and Technology, 1(3), 64-67.

Chrastil, J. (1987). Improved Calorimetric Determination of Amylose in Starches of Flours. Carbohydrate Research, 159: 154158.

Duboise M. N. Gruillies, K.A, Hamilton, J. K, Rogers, P.A. and Smith, F. (1956). Colorimetric Method for Determination of Sugars and Related Substances. Anal Chem 28 : 350-6.

Evans, J. D., and Haismann, D. R. (1982). The Effect of Solutes on the Gelatinization Temperature slight variation in some cases. Thus the paper concludes that with very minor modification, the starch can be used as alternative for industrial products in the starch industry

of Potato Starch. Starch/Staerke, 34, 224231.

Ezeagu, I. E., Metges, C. C., Proll, J. Petzke, K. J. and Akinsoyinu, A. O. (2011). Chemical Composition and Nutritive Value of Some Wild-Gathered Tropical Plant Seeds. Retrieved on February 3 from: http//:www.chemcomandnutrient.

General Tests (2011). Powder Particle Size Determination. JP XIV. Pp. 77 - 78.

Hoover, R. and Senanayake, S. P. J. N. (1996). Composition and Physiochemical Properties of Oat Starch. Food Research International, 29 (1), 15-26.

Hoover, R.; Hughes, T.; Chung, H. J. and Liu, Q. (2010). Composition, Molecular Structure, Properties, and Modification of Pulse Starches: A review. Food Research International. 43, 399-413.

Ismail A. E., (1998); Effect of Soil Amendments with Some Hardwood Barks on Reproduction of Rotylenchulus Reniformis and Growth of Sunflower. Pakistan Journal of Nematology. 6(2):137-144.

Kalenga K, Hood L. F. and Vansoest, P. J. (1981). Characterisation of Starch and Fiber of Banana Fruit. J Food Sci. 46: 1885-90.

Lee, H. C.; Htoon, A. K. and Paterson, J. L. (2007). Alkaline Extraction of Starch from Australian Lentil Cultivars: Matilda and Digger Optimised for Starch Yield and Starch and Protein Quality. Food Chemistry, 102, 551-559. 
Linus, A. J. (1995). Tableting Behaviour of Some Depolymerise Local Starches. An MSc.(Pharmaceutics) Dissertation, Ahmadu Bello Unviersity Zaria, Nigera, Pp. 42 - 45.

Madigan, E. (2003). New Uses for Starch. HealthGuidance for Better Health. Retrieved on 20/1/2011 from: http://www.healthguidance.org/pages/Terms -of-Service

Marton, G. (2003). Non-Food Applications of Starch. Interactive European Network for Industrial Crops and their Applications. (IENICA) Newsletter No. 19, March, 2003. retrieved on 20/1/2011 from http://www.ienica.net/newsletters/newsletter 19.pdf

Miles, M. J., Morris, V. J., Orford, P. D., and Ring, S. G. (1985). The roles of Amylose and Amylopectin in the Gelation and Retrogradation of Starch. Carbohydrate Research, 35, 271-278.

Nadiha, M. Z. N; Fazilah, A.; Bhat, R. and Karim, K. A. (2010). Comparative Susceptibilities of Sago, Potato and Corn Starches to Alkali Treatment. Food Chemistry, (121), 10531059.

Odeku O. A and Itiola. A. (2007). Compaction Properties of Three Types of Starch. Iranian Journal of Pharmaceutical Research (IJPR), 6 (1): 17-23.

Orwa, C.; Mutua, A.; Kindt, R.; Jamnadass, R.; and Simons, A. (2009); Agroforestree Database:a tree reference and selection guide version 4.0. Retrieved on 12/4/2011from http://www.worldagroforestry.org/af/treedb/

Rocher, M. (2003). New Market Outlet for Starch in France. Interactive European Network for Industrial Crops and their Application (IENICA). Newsletter No. 19. P. 2.

Sandhu, K. S. and Singh, N. (2007). Some Properties of Corn Starches II: Physicochemical, Gelatinization, Retrogradation, Pasting and Gel Textural Properties. Food Chemistry. 101, 1499-1507

Schwartz, D. and Whistler, R. L. (2009). History and Future of Starch: Chapter 1 in BeMiller, J. and Whistler, R. (Ed). Starch: Chemistry and Technology. ( $3^{\text {rd }}$ ed). (P 5). Amsterdam: Elsevier.

Science Tech Entrepreneur (2010). Starch - The Booming Industry Retrieved February, 3, 2011 from: http://www.wisconsinpotatoes.com/ PDF/Te achersInfo/Starchsources.pdf

Shannon, J. C.; Garwood, D. L. and Boyer, C. D. (2009). Genetics and Physiology of Starch Development: Chapter 3. In BeMiller, J. and Whistler, R. (Ed). Starch: Chemistry and Technology. ( $3^{\text {rd }}$ ed). (Pp. 24 - 25). Amsterdam: Elsevier.
Teli, M. D., Rohera, P.; Sheikh, J. and Singhal, R. (2009). Application of Germinated Maize Starch in Textile Printing. Carbohydrate Polymers. 75, 599 - 603.

Tester, R. F. and Morrison, W. R. (1990). Swelling and Gelatinization of Cereal Starches. Effect of Amylopectin, Amylose and Lipids. Cereal Chemistry. 67, $551-557$.

van der, van der , Uitdehaag, Leemhuis and Dijkhuizen (2002). Properties and Applications of Starch-Converting Enzymes of the Alpha-amylase Family. J Biotechnol., 94(2):137-55.

Vasanthan, T. (2001). Overview of Laboratory Isolation of Starch from Plant Materials. Current Protocols in Food Analytical Chemistry. E2.1.1-E2.1.6

Verwimp, T.; Vandeputte, G. E.; Marrant, K. and Delcour, J. A. (2004). Isolation and Characterisation of Rye Starch. Journal of Cereal Science. 39, 85 - 90.

Yuan, Y.; Zhang, L.; Dai, Y. and Yu, J. (2007). Physicochemical Properties of Starch obtained from Dioscorea nipponica Makino Comparison with Other Tuber Starches. Journal of Food Engineering. 82, 436 - 442. 